\title{
Infectious background of patients with a history of acute anterior uveitis
}

\author{
M Huhtinen, K Laasila, K Granfors, M Puolakkainen, I Seppälä, L Laasonen, H Repo, \\ A Karma, M Leirisalo-Repo
}

Ann Rheum Dis 2002;61:1012-1016

\begin{abstract}
Objective: To study the infectious backround of patients with a history of acute anterior uveitis (AAU) and healthy control subjects.

Methods: Sixty four patients with previous AAU and 64 sex and age matched controls were studied. Serum antibodies to Salmonellae, Yersiniae, Klebsiella pneumoniae, Escherichia coli, Proteus mirabilis, Campylobacter jejuni, and Borrelia burgdorferi were measured using enzyme linked immunosorbent assay (ELISA), and antibodies to Chlamydia trachomatis and Chlamydia pneumoniae by microimmunofluorescence test. Peripheral blood mononuclear cells (PBMCs), separated by density gradient centrifugation, were studied for Salmonella and Yersinia antigens by means of an immunofluorescence test, and for $C$ pneumoniae DNA with a polymerase chain reaction (PCR). Results: Neither prevalence nor levels of single microbial antibodies studied differed between the patients and control subjects, or between subgroups of patients created on the basis of clinical characteristics. In logistic regression analysis, the high number of recurrences (>10) of AAU was independently related to the presence of single or multiple bacterial antibodies $(p=0.04)$. None of the PBMC samples of the patients were positive for Yersinia or Salmonella antigens. C pneumoniae PCR was positive in a patient who was negative for $C$ pneumoniae antibodies. Conclusion: Although neither the prevalence nor the levels of single microbial antibodies studied differed between the patients and the controls, current data suggest that the presence of single or multiple antibodies in patients with many recurrences of AAU compared with patients with none or few recurrences may be a sign of repeated infections, antigen persistence, or raised innate immune responsiveness.
\end{abstract}

See end of article for authors' affiliations

Correspondence to: Dr Minna Huhtinen, Helsinki University Eye Hospital, PO Box 220, FIN-00029 HUS, Finland minna.huhtinen@hus.fi

Accepted 16 April 2002

A cute anterior uveitis (AAU) is a member of the spondyloarthropathy (SpA) family, which includes various seronegative arthritides such as ankylosing spondylitis (AS), a prototype of SpA, and reactive arthritis (ReA). Although the aetiopathology of SpA is not known, it is considered to involve genetic factors and environmental factors such as infections. ${ }^{1}$ More than $50 \%$ of patients with AAU are positive for the HLA-B27 antigen. ${ }^{2}$ AAU occurs in 5\% of patients with acute ReA. ${ }^{3}$ Among patients with AAU but no signs of ReA, bacteria indicating an infectious cause are not often detected. If detected, they include gastrointestinal pathogens such as Salmonellae and Yersiniae ${ }^{5}$ and urogenital pathogens such as Chlamydia trachomatis, ${ }^{6}$ all of which serve as triggers of ReA as well. Borrelia burgdorferi has also been associated with both AAU and ReA. ${ }^{78}$ Recently, Chlamydia pneumoniae, a respiratory tract pathogen, was associated with $\mathrm{ReA}^{9}$ and AAU. ${ }^{10}$ In patients with ReA, the presence of microbial antigens in the joint has been demonstrated for Chlamydia trachomatis, ${ }^{11}$ Yersinia, ${ }^{12}$ Salmonella, ${ }^{13}$ and Shigella. ${ }^{14}$ Also, microbial antigens can persist for prolonged periods in the circulation, ${ }^{15}$ in the gut, or in the skin. ${ }^{16}$ In AS, it has been suggested that Klebsiella species play a part in the exacerbation of the disease ${ }^{17}$ as well as in the development of AAU. ${ }^{18}$

Many aetiopathological features of AAU are shared with ReA. Unlike patients with ReA, little is known about antigen persistence in patients with AAU. We therefore measured the prevalence and serum levels of bacterial antibodies in patients with a history of AAU, and studied the presence of Salmonella and Yersinia antigens and C pneumoniae DNA in peripheral blood mononuclear cells (PBMCs). We compared the findings with healthy control subject material studied simultaneously.

\section{PATIENTS AND METHODS}

A total of 64 patients with idiopathic acute or recurrent anterior uveitis were first examined in the Helsinki University Eye Hospital between 1993 and 1996 and then again between September and December 1999 at a follow up visit. A visual acuity test, tonometry, a slit lamp examination, and an evaluation of the fundus with a 90 diopter lens, or indirect ophthalmoscopy, and a three mirror lens when necessary, were performed. Data on age, sex, age at onset of first uveitis, number of attacks, complications, and systemic symptoms and disorders were collected on standard forms. A rheumatological survey including a detailed history of the occurrence of musculoskeletal, abdominal, and skin diseases and completed with sacroiliac radiographic examination was performed on the patients with low back pain or peripheral joint symptoms suggestive of AS or other forms of SpA. Patients fulfilling the criteria of the European Spondylarthropathy Study Group were diagnosed as having seronegative $\mathrm{SpA}^{19}$. Sixty four healthy sex and age matched subjects of the hospital and laboratory staff or their acquaintances served as controls. They did not have a history of AAU or SpA.

\section{Blood samples and routine laboratory tests}

Serum samples for antibody detection were stored at $-20^{\circ} \mathrm{C}$ until tested simultaneously. The PBMCs were isolated using

Abbreviations: $\mathrm{AAU}$, acute anterior uveitis; $\mathrm{AS}$, ankylosing spondylitis; EIA, enzyme immunoassay; ELISA, enzyme linked immunosorbent assay; MIF, microimmunofluorescence; PBMC, peripheral blood mononuclear cells; PCR, polymerase chain reaction; $\mathrm{ReA}$, reactive arthritis; $\mathrm{SpA}$ spondyloarthropathy 
Vacutainer CPT cell preparation tubes with sodium citrate (Becton Dickinson Vacutainer Systems, Becton Dickinson and Co, Franklin Lakes, NJ, USA) according to the manufacturer's recommendations. From a proportion of the PBMC fraction, cytocentrifuge preparations were made and stored at $-20{ }^{\circ} \mathrm{C}$ until stained for microbial antigens. From another proportion, DNA was extracted using QIAamp DNAkit (Qiagen, Valencia, CA, USA) and stored at $-70{ }^{\circ} \mathrm{C}$ until used for $C$ pneumoniae polymerase chain reaction (PCR). Routine laboratory tests (erythrocyte sedimentation rate, $\mathrm{C}$ reactive protein, blood cell count, Treponema pallidum haemagglutination assay, urine sediment) were also performed.

\section{Antibodies to Salmonellae, Yersiniae, Klebsiella pneumoniae, Escherichia coli, and Proteus mirabilis} Yersinia enterocolitica O:3 and O:9, Yersinia pseudotuberculosis I and III, E coli and P mirabilis were clinical isolates. For Salmonella, combined lipopolysaccharides from Salmonella enteritidis and Salmonella typhimurium (Sigma Chemical Co, St. Louis, MO, USA) were used as antigens. ${ }^{20} S$ enteritidis, $S$ typhimurium and other Salmonellae belonging to groups B or D are responsible for about $90 \%$ of Salmonella infections diagnosed by bacterial isolation in Finland. The remaining Salmonella subtypes are probably also recognised by this ELISA, although with less efficiency. ${ }^{20}$ Klebsiella pneumoniae strains 21 and 43 (Dr AF Geczy, New South Wales Red Cross Blood Transfusion Service, Sydney, Australia) and ATCC 27736 (the American Type Culture Collection, Rockville, MD, USA) were chosen on the basis of previous studies. ${ }^{21-23}$ The antigen extracts were prepared as previously described. ${ }^{24}$

Polystyrene microtitre plates (Nunc, Roskilde, Denmark) were coated with the antigen preparations and then used to determine the prevalence of specific antibodies, as described previously. ${ }^{20-24}$ Antibody concentrations are expressed as enzyme immunoassay (EIA) units where one EIA unit is $1 / 100$ of the corresponding antibody concentration in the positive reference serum. Antibody titres at least two standard deviations above the mean of a healthy control person were regarded as positive.

\section{Antibodies to Campylobacter jejuni}

The antigen for the ELISA measurement of antibodies to Campylobacter was an acid extract of $C$ jejuni strain 143483 prepared and used as earlier described. ${ }^{25}$ Titre levels of 3500 or more for IgG, 5000 for IgA, and 2500 for IgM were considered to indicate previous infection due to $C$ jejuni.

\section{Antibodies to $C$ pneumoniae and $C$ trachomatis}

Antibodies specific for $C$ pneumoniae and $C$ trachomatis were both measured by the microimmunofluorescence (MIF $)^{26} 27$ test. Antibody titres of $\geqslant 1 / 512$ in the IgG fraction, $\geqslant 1 / 16$ in the $\operatorname{Ig} M$ fraction, or $\geqslant 1 / 160$ in the $\operatorname{IgA}$ fraction were considered to indicate ongoing infection, and a titre of $1 / 32-1 /$ 256 for IgG was considered to indicate previous infection. $C$ trachomatis antibodies were also studied by MIF. ${ }^{27}$

\section{Antibodies to $B$ burgdorferi}

IgG and IgM antibodies to $B$ burgdorferi were measured using the Lyme ELISA (Dako, Glostrup, Denmark), modified by end point titration. ${ }^{28}$

\section{Immunofluorescence staining of peripheral blood} mononuclear cells for Salmonella and Yersinia antigens The cytocentrifuge slides were stained with mouse monoclonal antibodies specific for O-polysaccharide chains of lipopolysaccharides of S enteritidis (MASE O9), ${ }^{29}$ S typhimurium (MAST O4), ${ }^{29} Y$ enterocolitica O:3 (A6), ${ }^{12}{ }^{15} 30$ and the heat shock protein of $Y$ enterocolitica O:3 (IV7D2). ${ }^{15} 31$ Each slide was read by one of the authors (KG) - who was blinded to the source of the cells-and were analysed using a fluorescence microscope
(Leitz diaplan incidence light fluorescence microscope with an Osram HBO 100 watt mercury lamp (Leitz, Wetzzlar, Germany).

\section{$C$ pneumoniae polymerase chain reaction}

C pneumoniae DNA was detected as described previously. ${ }^{32} 33$ The DNA preparation at $-70{ }^{\circ} \mathrm{C}$ was thawed and amplified by $C$ pneumoniae specific nested primers in a touchdown PCR. The amplified products were detected by agarose gel electrophoresis.

\section{HLA-B27 typing}

The presence of HLA-B27 antigen was determined using either the standard microlymphocytotoxity technique or PCR of the diagnostic molecular genetics laboratory of the hospital. Briefly, DNA was amplified with primers B27/E136 as 5'-CGG CGG TCC AGG AGC T-3' 5'- and B27/E91 s + 5'-GGG TCT CAC ACC CTC CAG AAT-3'. Generation of the HLA-B27 PCR product was detected on agarose gel electrophoresis.

\section{Compliance with research ethics standards}

The study was approved by the local ethics committee and conducted according to the tenets of the Declaration of Helsinki. Informed consent was obtained from all the patients and control subjects.

\section{Statistical analysis}

The variables had a non-normal distribution and were analysed with the Mann-Whitney U test. Categorical data were analysed by Pearson's $\chi^{2}$ test or Fisher's exact test. To estimate dependencies between the presence of antibodies and the patients' characteristics we used a logistic regression model. Clinically important variables were chosen for the analysis. The forward selection method was used and cut off values were set at 0.2 for the variable selection.

\section{RESULTS}

\section{Patients}

There were 64 patients ( 38 men and 26 women) with a mean age of 45.4 (SD 12.8) years at the follow up. Fifty five (86\%) of the patients and six $(9 \%)$ of the sex and age matched healthy control subjects were HLA-B27 positive. Eighty four per cent of the patients had had a recurrent attack. The mean age at the onset of the first AAU was 34.2 (SD 11.6, range 14-64) years, and time between the first attack and the follow up visit was 11.1 (SD 9.6) years.

Twenty five per cent of the patients had developed SpA; $27 \%$ had been affected by eye complications (persistent synechiae, cataract, cystoid macular degeneration, and posterior or panuveitis). Seven patients had more than one complication in each eye, and three patients had complications in both eyes. In $11 \%$ of the patients anterior uveitis had became chronic. The ocular complications were not associated with the presence of SpA (table 1).

\section{Occurrence of antibodies in patients and control subjects}

The prevalence of the antibodies to $Y$ enterocolitica and $Y$ pseudotuberculosis III, Salmonellae, K pneumoniae, P mirabilis, E coli, Chlamydia, and Borrelia species for the patients and the control subjects was much the same (table 2). Patients with AAU had antibodies to $Y$ pseudotuberculosis I more often than the control subjects $(28 \% v 11 \%, \mathrm{p}=0.01$; table 2$)$. However, if corrected for the number of comparisons performed, the difference was not significant.

The antibody levels against enterobacteriacae (Yersiniae, $K$ pneumoniae, C jejuni, E coli, and $P$ mirabilis), C pneumoniae, $C$ trachomatis, and $B$ burgdorferi, did not differ between the patients and the control subjects. An exception was the higher level of IgG antibodies to Salmonellae found in the controls $(p=0.018)$. 
Table 1 Characteristics of the 64 patients with previous acute anterior uveitis (AAU) at the time of the follow-up examination

\begin{tabular}{lcc}
\hline Characteristics & Patients $\mathrm{n}$ & $\%$ \\
\hline HLA-B27 antigen positivity & 55 & 86 \\
Recurrences of AAU: & 10 & 16 \\
$\quad$ None & 32 & 50 \\
$\leqslant 10$ & 22 & 34 \\
$>10$ & 7 & 11 \\
Chronic eye disease & 17 & 27 \\
Eye complications & 9 & 7 \\
Cataract† & 5 & 4 \\
Cystoid macular degeneration $\dagger$ & 0 & 0 \\
Glaucoma & 13 & 10 \\
Persistent synechiae $\dagger$ & 2 & 2 \\
$\quad$ Posterior uveitis or panuveitis $\dagger$ & 7 & 11 \\
More than one complication per eye & 3 & 5 \\
Complications in both eyes & 16 & 25 \\
Spondyloarthropathy & & \\
\hline
\end{tabular}

* Iritis not resolved within three months; †data are number of eyes affected with complications.

Increased $\operatorname{IgM}$ antibodies to $Y$ pseudotuberculosis I were measured more often in the patients than controls $(p=0.03)$. When corrected for the number of comparisons made, the results were not significant.

\section{Occurrence of antibodies in subgroups of patients}

Sex, age at examination, eye complications, development of SpA, recurrences, time since the first AAU, HLA-B27 antigen, or chronic course of the disease did not correlate with antibody positivity (table 3 ). When a detailed analysis was made, the patients with eye complications had higher levels of IgA antibodies to $P$ mirabilis ( $p=0.003$ when corrected for the numbers of comparisons, $\mathrm{p}=0.042$ ) than those without eye complications.

Four male patients and one female patient had a recurrent uveitis attack at the time of the examination. None of the patients had symptoms of clinical infection within six months before the recruitment or antibody levels diagnostic of recent infection. In the logistic regression analysis to explore whether a dependency between positive antibody levels $(\geqslant 4$ standard deviations of controls for Enterobactericae and cut off values as mentioned in methods section for Campylobacter, Borrelia, and Chlamydia species) and the patients' characteristics existed, the independent variables were sex, age at onset of AAU, ocular complications, spondyloarthropathies, time since the first AAU, and number of recurrences $(\leqslant 10$ recurrences $v$ $>10$ recurrences). The number of the recurrences was the only variable of significance in relation to presence of antibodies against one or several bacteria $(\mathrm{p}=0.047)$.

\section{Antigen persistence}

None of the patients had persisting Yersinia or Salmonella antigens in their PBMCs. C pneumoniae DNA was detected in one of the patients who was not positive for $C$ pneumoniae antibodies. All the controls were negative for $C$ pneumoniae DNA.

\section{DISCUSSION}

In our study, patients with a history of many recurrences of AAU had raised antimicrobial antibody levels against one or several bacteria tested more often than patients with none or few recurrences. Such a high prevalence of antibodies could be a mark of subclinical infections in the gut or in the urogenital region or of increased penetrance of microbial antigens. Ebringer et al were the first to show that isolation of Klebsiella from faecal samples is related to the activation of AS and uveitis. ${ }^{34}$ Later, it was found that antibodies occur against different intestinal and urogenital microbes in association with
Table 2 Prevalence of antibodies in patients $(n=64)$ and control subjects $(n=64)$

\begin{tabular}{|c|c|c|}
\hline Prevalence of antibodies & Patients n (\%) & Controls n (\%) \\
\hline \multicolumn{3}{|l|}{ Salmonellae: } \\
\hline $\lg A$ & $4(6)$ & $5(8)$ \\
\hline $\lg G$ & $2(3)$ & $2(3)$ \\
\hline $\lg M$ & $5(8)$ & $3(5)$ \\
\hline Total positive & $10(16)$ & $8(13)$ \\
\hline \multicolumn{3}{|l|}{ Yersinia enterocolitica $0: 3$ : } \\
\hline $\lg \mathrm{A}$ & $2(3)$ & $2(3)$ \\
\hline $\lg G$ & $3(5)$ & $3(5)$ \\
\hline $\lg M$ & $1(2)$ & $5(8)$ \\
\hline Total positive & $6(9)$ & 9 (14) \\
\hline \multicolumn{3}{|l|}{ Yersinia enterocolitica 0:9: } \\
\hline $\lg A$ & $0(0)$ & $2(3)$ \\
\hline $\lg G$ & $2(3)$ & $4(6)$ \\
\hline $\lg M$ & $3(5)$ & $4(6)$ \\
\hline Total positive & $5(8)$ & 8 (13) \\
\hline \multicolumn{3}{|c|}{ Yersinia pseudotuberculosis I: } \\
\hline $\lg \mathrm{A}$ & $3(5)$ & $3(5)$ \\
\hline $\lg G$ & $6(9)$ & $3(5)$ \\
\hline $\lg M$ & $10(16)$ & $2(3)$ \\
\hline Total positive & $18(28)^{*}$ & 7 (11) \\
\hline \multicolumn{3}{|c|}{ Yersinia pseudotuberculosis III: } \\
\hline $\lg \mathrm{A}$ & $4(6)$ & $4(6)$ \\
\hline $\lg G$ & $1(2)$ & $4(6)$ \\
\hline $\lg M$ & $4(6)$ & $3(5)$ \\
\hline Total positive & 9 (14) & 9 (14) \\
\hline \multicolumn{3}{|c|}{ Klebsiella pneumoniae strain 43: } \\
\hline $\lg \mathrm{A}$ & $10(16)$ & $3(5)$ \\
\hline $\lg G$ & $3(5)$ & $4(6)$ \\
\hline $\lg M$ & $5(8)$ & $4(6)$ \\
\hline Total positive & $14(22)$ & 9 (14) \\
\hline \multicolumn{3}{|c|}{ Klebsiella pneumoniae strain 21: } \\
\hline $\lg \mathrm{A}$ & $2(3)$ & $3(5)$ \\
\hline $\lg G$ & $3(5)$ & $3(5)$ \\
\hline $\lg M$ & $2(3)$ & $3(5)$ \\
\hline Total positive & $5(8)$ & $8(13)$ \\
\hline \multicolumn{3}{|c|}{ Klebsiella pneumoniae strain ATCC27736: } \\
\hline $\lg \mathrm{A}$ & $6(9)$ & $4(6)$ \\
\hline $\lg G$ & $1(2)$ & $3(5)$ \\
\hline $\lg M$ & $1(2)$ & $2(3)$ \\
\hline Total positive & 7 (11) & 7 (11) \\
\hline \multicolumn{3}{|l|}{ Campylobacter jejuni: } \\
\hline $\lg A$ & $0(0)$ & $0(0)$ \\
\hline $\lg G$ & $4(6)$ & $2(3)$ \\
\hline $\lg M$ & $0(0)$ & $0(0)$ \\
\hline Total positive & $4(6)$ & $2(3)$ \\
\hline \multicolumn{3}{|l|}{ Proteus mirabilis: } \\
\hline $\lg A$ & $5(8)$ & $3(5)$ \\
\hline $\lg G$ & $1(2)$ & $3(5)$ \\
\hline $\lg M$ & $5(8)$ & $3(5)$ \\
\hline Total positive & $9(14)$ & $8(13)$ \\
\hline \multicolumn{3}{|l|}{ Escherichia coli: } \\
\hline $\lg A$ & $3(5)$ & $5(8)$ \\
\hline $\lg G$ & $5(8)$ & $2(3)$ \\
\hline $\lg M$ & $2(3)$ & $6(9)$ \\
\hline Total positive & $6(9)$ & $13(20)$ \\
\hline \multicolumn{3}{|l|}{ Chlamydia trachomatis: } \\
\hline $\lg A$ & $1(2)$ & $0(0)$ \\
\hline $\lg G$ & $3(5)$ & $4(6)$ \\
\hline $\lg M$ & $0(0)$ & $0(0)$ \\
\hline Total positive & $3(5)$ & $4(6)$ \\
\hline \multicolumn{3}{|l|}{ Chlamydia pneumoniae: } \\
\hline $\lg A$ & $2(3)$ & $22(34)$ \\
\hline $\lg G$ & $36(56)$ & $46(72)$ \\
\hline $\lg M$ & $2(3)$ & $0(0)$ \\
\hline Total positive & 38 (59) & $46(72)$ \\
\hline Borrelia burgdorferi: & & \\
\hline $\lg G$ & $0(0)$ & $1(2)$ \\
\hline $\lg M$ & $0(0)$ & $1(2)$ \\
\hline Total positive & $0(0)$ & $2(3)$ \\
\hline
\end{tabular}


Table 3 Presence of antibodies in relation to clinical characteristics of the patients

\begin{tabular}{|c|c|c|}
\hline Characteristics & $\begin{array}{l}\text { Patients without } \\
\text { antibodies } n\end{array}$ & $\begin{array}{l}\text { Patients with } \\
\text { antibodies* } n \text { (\%) }\end{array}$ \\
\hline \multicolumn{3}{|l|}{ Sex: } \\
\hline Men & 5 & $33(87)$ \\
\hline Women & 3 & $23(88)$ \\
\hline \multicolumn{3}{|c|}{ Age at examination: } \\
\hline$\leqslant 40$ years & 4 & $22(85)$ \\
\hline$>40$ years & 4 & $34(89)$ \\
\hline \multicolumn{3}{|c|}{ Years from the first $\mathrm{AAU}$ : } \\
\hline$\leqslant 10$ years & 6 & $39(87)$ \\
\hline$>10$ years & 2 & $17(89)$ \\
\hline \multicolumn{3}{|c|}{ Eye complications: } \\
\hline None & 4 & $43(91)$ \\
\hline Yes & 4 & $13(76)$ \\
\hline \multicolumn{3}{|c|}{ Spondyloarthropathy: } \\
\hline None & 7 & $41(85)$ \\
\hline Yes & 1 & $15(94)$ \\
\hline \multicolumn{3}{|c|}{ HLA-B27 antigen: } \\
\hline Negative & 2 & $7(78)$ \\
\hline & 6 & 49 (89) \\
\hline \multicolumn{3}{|c|}{ Chronic eye disease: $\dagger$} \\
\hline No & 7 & $50(88)$ \\
\hline Yes & 1 & $6(86)$ \\
\hline
\end{tabular}

*Table 2 presents the prevalence of antibodies to individual bacteria. †lritis not resolved within three months.

AAU in patients with AS, such as increased IgA antibody levels against $K$ pneumoniae and $E$ coli lipopolysaccharide ${ }^{35}$ and higher frequency of IgG antibodies to $C$ trachomatis. ${ }^{36}$ We found in the present study that the patients with eye complications had increased levels of IgA antibodies against $P$ mirabilis. The high prevalence of antibodies found may indicate that the patients had been exposed to the bacteria in the past. A single increasaed antibody level may derive from prolonged antigen persistence as found in patients with $\mathrm{SpA}^{16}$ and ReA. ${ }^{37} 38$ Bacterial antigens, DNA, and RNA have been shown to persist in the synovial membrane, ${ }^{39-42}$ synovial fluid cells, ${ }^{11-14}{ }^{43-45}$ and peripheral blood cells $s^{13}{ }^{46} 47$ in patients with ReA. However, the pathogenetic implications of antigen persistence remain uncertain because Chlamydial DNA has also been found in the joints of patients with rheumatoid arthritis, ${ }^{46}$ and in asymptomatic subjects, ${ }^{47}$ and Shigella or Yersinia antigens have been found in peripheral blood cells in patients years after uncomplicated enteric infections. ${ }^{14} 15$ The negative findings in the search for antigenic material in PBMCs in our study do not support the hypothesis that antigen persistence would be a common feature in patients with previous AAU.

In experimental studies, bacterial invasion into HLA-B27 transfected cells has been shown to be decreased, ${ }^{48}$ unchanged, ${ }^{49}$ or increased. ${ }^{50}$ Although rats and mice transgenic for HLA-B27 show enhanced susceptibility to bacterial infections, ${ }^{51}{ }^{52}$ the expression of HLA-B27 does not influence the incidence or severity of uveitis in the bacterially induced AAU model..$^{53}$ HLA-B27 diminished elimination of Salmonella in monocytic U937 cells transfected with HLA-B27. ${ }^{54}$

The raised antibody levels found in the present study may derive from high innate immune responsiveness. In accordance with this possibility, Ikawa et al used Hela cells transfected with HLA-B27 gene to provide evidence suggesting that HLA-B27 may be associated with the activation of otherwise silent intracellular signal transduction pathways and may also contribute to the activation of innate immune genes. ${ }^{55}$ In addition, Ekman has shown that the impaired capacity of Salmonella permissive, HLA-B27 transfected, human monocytic U937 cells to clear Salmonella is associated with the high production of tumour necrosis factor $\alpha$ and interleukin $10 .^{56}$ These findings, obtained under in vitro conditions, are indeed in agreement with our recently reported results showing raised tumour necrosis factor $\alpha$ pro- duction in patients with previous AAU compared with healthy controls. ${ }^{57}$ Taken together, the mechanisms described above may enhance phagocytic antigen processing or presentation capacity at the early steps of an immune response. ${ }^{58}$

To conclude, current data suggest that raised antibody responses in this group of patients with a high frequency of HLA-B27 and with many recurrences of AAU compared with patients with none or few recurrences may be a sign of repeated infections, antigen persistence, or innate immune responsiveness

\section{ACKNOWLEDGEMENT}

This work was supported by the Friends for the Blind, the Eye Foundation, and the Finnish Cultural Foundation.

\section{Authors' affiliations}

M Huhtinen, A Karma, Department of Ophthalmology, University of Helsinki, Helsinki, Finland

K Laasila, M Leirisalo-Repo, Division of Rheumatology, University of Helsinki, Helsinki, Finland

K Granfors, National Public Health Institute, Department in Turku, Turku, Finland

M Puolakkainen, Department of Virology, University of Helsinki, Helsinki, Finland

I Seppälä, H Repo, Department of Bacteriology and Immunology, University of Helsinki, Helsinki, Finland

L Laasonen, Department of Radiology, University of Helsinki, Helsinki, Finland

H Repo, Division of Infectious Diseases, University of Helsinki, Helsinki, Finland

\section{REFERENCES}

1 Rose NR. The role of infection in the pathogenesis of autoimmune disease. Semin Immunol 1998;10:5-13

2 Brewerton DA, Caffrey M, Nicholls A, Walters D, James DCO. Acute anterior uveitis and HL-A27. Lancet 1973;ii:994-6.

3 Leirisalo M, Skylv G, Kousa M, Voipio-Pulkki L-M, Suoranta H, Nissilä $M$, et al. Followup study on patients with Reiter's disease and reactive arthritis, with special reference to HLA-B27. Arthritis Rheum 1982;25:249-59.

4 Saari KM, Vilppula A, Lassus A, Leirisalo M, Saari R. Ocular inflammation in Reiter's disease after Salmonella enteritis. Am J Ophthalmol 1980;90:63-8.

5 Mattila L, Granfors K, Toivanen A. Acute anterior uveitis after yersinia infection. Br J Ophthalmol 1982;66:209-12.

6 Mattila L, Salminen L, Terho P. Chlamydial immunofluorescence serology in anterior uveitis. Br J Ophthalmol 1982:66:654-7.

7 Karma A, Seppälä I, Mikkilä H, Kaakkola S, Viljanen M, Tarkkanen A. Diagnosis and clinical characteristics of ocular Lyme borreliosis. Am J Ophthalmol 1995;1 19:127-35.

8 Weyand CM, Goronzy JJ. Immune responses to Borrelia burgdorferi in patients with reactive arthritis. Arthritis Rheum 1989;32:1057-64.

9 Braun J, Laitko S, Treharne J, Eggens U, Wu P, Distler A, et al. Chlamydia pneumoniae: a new causative agent of reactive arthritis and undifferentiated oligoarthritis. Ann Rheum Dis 1994;53:100-5.

10 Huhtinen M, Puolakkainen M, Laasila K, Sarvas M, Karma A, Leirisalo-Repo M. Chlamydial antibodies in patients with previous acute anterior uveitis. Invest Ophthalmol Vis Sci 2001;42:1816-9.

11 Keat A, Thomas B, Dixey J, Osborn M, Sonnex C, Taylor-Robinson D. Chlamydia trachomatis and reactive arthritis: the missing link. Lancet 1987;i:72-4.

12 Granfors K, Jalkanen S, von Essen R, Lahesmaa-Rantala R, Isomäki $O$ Pekkola-Heino K, et al. Yersinia antigens in synovial-fluid cells from patients with reactive arthritis. N Engl J Med 1989;320:216-21.

13 Granfors K, Jalkanen S, Lindberg AA, Mäki-lkola O, von Essen R, Lahesmaa-Rantala $R$, et al. Salmonella lipopolysaccharide in synovial cells from patients with reactive arthritis. Lancet 1990;335:685-8.

14 Granfors K, Jalkanen S, Toivanen P, Koski J, Lindberg AA. Bacterial lipopolysaccharide in synovial fluid cells in Shigella triggered reactive arthritis. J Rheumatol 1992;19:500.

15 Granfors K, Merilahti-Palo R, Luukkainen R, Möttönen T, Lahesmaa R, Probst $P$, et al. Persistence of Yersinia antigens in peripheral blood cells from patients with Yersinia enterocolitica O:3 infection with or without reactive arthritis. Arthritis Rheum 1998;41:855-62.

16 Hoogkamp-Korstanje JA, de Koning J, Heesemann J. Persistence of Yersinia enterocolitica in man. Infection 1988;16:81-5.

17 Shodjai-Moradi F, Ebringer A, Abduljadayel I. IgA antibody response to Klebsiella in ankylosing spondylitis measured by immunoblotting. Ann Rheum Dis 1992;51:233-7.

18 Sprenkels SH, Uksila J, Vainionpää R, Toivanen P, Feltkamp TE. IgA antibodies in HLA-B27 associated acute anterior uveitis and ankylosing spondylitis. Clin Rheumatol 1996;1:52-6. 
19 Dougados M, van der Linden S, Juhlin R, Huitfeldt B, Amor B, Calin A, et al. The European Spondylarthropathy Study Group preliminary criteria for the classification of spondylarthropathy. Arthritis Rheum 1991;34:1218-27.

20 Isomäki O, Vuento R, Granfors K. Serological diagnosis of salmonella infections by enzyme immunoassay. Lancet 1989;i:1411-4.

21 Nissilä M, Lahesmaa R, Leirisalo-Repo M, Lehtinen K, Toivanen P, Granfors K. Antibodies to Klebsiella pneumoniae, Escherichia coli and Proteus mirabilis in ankylosing spondylitis: effect of sulfasalazine treatment. J Rheumatol 1994:21:2082-7.

22 Mäki-Ikola O, Penttinen M, von Essen R, Gripenberg-Lerche C, Isomäki $H$, Granfors K. IgM, lgG, and $\lg A$ class enterobacterial antibodies in serum and synovial fluid in patients with ankylosing spondylitis and rheumatoid arthritis. Br J Rheum 1997:36:1051-3.

23 Höhler T, Hug R, Schneider PM, Kummenauer F, Gripenberg-Lerche C, Granfors K, et al. Ankylosing spondylitis in monozygotic twins: studies on immunological parameters. Ann Rheum Dis 1999;58:435-40.

24 Granfors K, Lahesmaa-Rantala R, Ståhlberg TH, Toivanen A. Comparison of bacteria with and without plasmid-encoded proteins as antigens for measurement of immunoglobulin $M, G$ and $A$ antibodies to Yersinia enterocolitica by enzyme-linked immunosorbent assay. J Clin Microbiol 1989;27:583.

25 Rautelin H, Kosunen TU. An acid extract as a common antigen in Campylobacter coli and Campylobacter jejuni strains. J Clin Microbio 1983:17:700-1.

26 Wang SP, Grayston JT. Microimmunoflurescence serological studies with the TWAR organism. In: Oriel JD, Ridgeway G, Schachter J, Taylor-Robinson D, Ward M, eds. Chlamydial infections. Cambridge: Cambridge University Press; 1986:328-32.

27 Wang SP, Grayston JT, Alexander ER, Holmes KK. Simplified microimmunofluorescence test with trachoma lymphogranuloma venereum (Chlamydia trachomatis) antigen for use as a screening test for antibody. J Clin Microbiol 1975; 1:250-5.

28 Seppälä IJT, Kroneld R, Schauman K, Forsen K-O, Lassenius R. Diagnosis of Lyme borreliosis: non-specific serological reaction with Borrelia burgdorferi sonicate antigen caused by lgG2 antibodies. J Med Microbiol 1994;40:293-302

29 Granfors K, Jalkanen S, Lindberg AA, Mäki-lkola O, von Essen R, Lahesmaa-Rantala $R$, et al. Salmonella lipopolysaccharide in synovial cells from patients with reactive arthritis. Lancet 1990;335:685-8.

30 Pekkola-Heino K, Viljanen MK, Stahlberg TH, Granfors K, Toivanen A Monoclonal antibodies reacting selectively with core and O-polysaccharide of Yersinia enterocolitica O:3 lipopolysaccharide. Acta Pathol Microbiol Immunol Scand 1987;95:27-34.

31 Probst P, Hermann E, Meyer zum Buschenfelde KH, Fleischer B. Multiclonal synovial T cell response to Yersinia enterocolitica in reactive arthritis: the Yersinia 61-kDa heat-shock protein is not the major target antigen. J Infect Dis 1993; 167:385-91.

32 Boman J, Soderberg S, Forsberg J, Birgander LS, Allard A, Persson K, et al. High prevalence of Chlamydia pneumoniae DNA in peripheral blood mononuclear cells in patients with cardiovascular disease and in middle-aged blood donors. J Infect Dis 1998;178:274-7.

33 Tong CY, Sillis M. Detection of Chlamydia pneumoniae and Chlamydia psittaci in sputum samples by PCR. J Clin Pathol 1993:46:313-7.

34 Ebringer R, Cawdell D, Ebringer A: Association of Klebsiella pneumoniae with acute anterior uveitis in ankylosing spondylitis. BM 1979;i:383.

35 Mäki-Ikola O, Lehtinen K, Toivanen P, Granfors K. Antibodies to Klebsiella pneumoniae, Escherichia coli and Proteus mirabilis in the sera of ankylosing spondylitis patients with/without iritis and enthesitis. $\mathrm{Br} J$ Rheumatol 1995;34:418-20.

36 van der Paardt $M$, van Denderen JC, van den Brule JA, Morre SA, van der Horst-Bruinsma IE, Bezemer PD, et al. Prevalence of Chlamydia trachomatis in urine of male patients with ankylosing spondylitis is not increased. Ann Rheum Dis 2000:59:300-2.

37 Granfors K, Vilianen M, Tiilikainen A, Toivanen A. Persistence of IgM, $\lg G$, and $\lg A$ antibodies to Yersinia in Yersinia arthritis. J Infect Dis 1980;141:424-9.

38 Mäki-Ikola O, Leirisalo-Repo M, Kantele A, Toivanen P, Granfors K. Salmonella-specific antibodies in reactive arthritis. J Infect Dis 1991; 164:1141-8
39 Schumacher HR Jr, Magge S, Cherian PV, Sleckman J, Rothfuss S, Clayburne $G$, et al. Light and electron microscopic studies on the synovial membrane in Reiter's syndrome. Immunocytochemical identification of chlamydial antigen in patients with early disease. Arthritis Rheum 1988:31:937-46.

40 Merilahti-Palo R, Söderström K-O, Lahesmaa-Rantala R, Granfors K, Toivanen A. Bacterial antigens in synovial biopsy specimens in yersinia triggered reactive arthritis. Ann Rheum Dis 1991;50:87-90.

41 Hammer M, Nettelnbreker E, Hopf S, Schmitz E, Pörschke K, Zeidler H. Chlamydial rRNA in the joints of patients with Chlamydia-induced arthritis and undifferentiated arthritis. Clin Exp Rheumatol 1992:10:63-6.

42 Taylor-Robinson D, Gilroy CB, Thomas BJ, Keat ACS. Detection of Chlamydia trachomatis DNA in joints of reactive arthritis patients by polymerase chain reaction. Lancet 1992;340:81-2.

43 Viitanen A-M, Arstila TP, Lahesmaa R, Granfors K, Skurnik M, Toivanen $P$. Application of the polymerase chain reaction and immunofluorescence techiques to the detection of bacteria in Yersinia-triggered reactive arthritis. Arthritis Rheum 1991;34:89-96.

44 Nikkari S, Rantakokko K, Ekman P, Möttönen T, Leirisalo-Repo M, Virtala $M$, et al. Salmonella-triggered reactive arthritis: Use of polymerase chain reaction, immunocytochemical staining, and gas chromatography-mass spectrometry in the detection of bacterial components from synovial fluid. Arthritis Rheum 1999:42:84-9.

45 Bas S, Griffais R, Kvien TK, Glennås A, Melby K, Vischer TL. Amplification of plasmid and chromosome Chlamydia DNA in synovia fluid of patients with reactive arthritis and undifferentiated seronegative oligoarthropathies. Arthritis Rheum 1995;38:1005-13.

46 Schumacher HR, Arayssi T, Branigan P, Gerard H, Klippel J, Pando J, et al. Surveying for evidence of synovial Chlamydia trachomatis by polymerase chain reaction (PCR). A study of 411 synovial biopsies and synovial fluids (SF). Arthritis Rheum 1997;40:S270.

47 Schumacher HR, Arayssi T, Crane M, Lee J, Gerard H, Hudson AP, et al. Chlamydia trachomatis nucleic acids can be found in the synovium of some asymptomatic subjects. Arthritis Rheum 1999;42:1281-4.

48 Kapasi K, Inman RD. HLA-B27 expression modulates gram-negative bacterial invasion into transfected L cells. J Immunol 1992; 148:3554-9.

49 Huppertz HI, Heesemann J. The influence of HLA-B27 and interferon- $\gamma$ on the invasion and persistence of Yersinia in primary human fibroblasts. Med Microbiol Immunol 1996: 185:163-70.

50 Virtala M, Kirveskari J, Granfors K. HLA-B27 modulates the survival of Salmonella enteritidis in transfected $L$ cells, possibly by impaired nitric oxide production. Infect Immun 1997;65:4236-42.

51 Nickerson LD, Luthra HS, Savarirayan S, David CS. Susceptibility of HLA-B27 transgenic mice to Yersinia enterocolitica infection. Hum Immunol 1990;28:382-96.

52 Warner TF, Madsen J, Starling J, Wagner RD, Taurog JD, Balish E. Human HLA-B27 gene enhances susceptibility of rats to oral infection by Listeria monocytogenes. Am J Pathol 1996; 149:1737-43.

53 Baggia S, Lyons JL, Angell E, Barkhuizen A, Han YB, Planck SR, et al. A novel model of bacterially-induced acute anterior uveitis in rats and the lack of effect from HLA-B27 expression. J Invest Med 1997;45:295-301.

54 Laitio P, Virtala M, Salmi M, Pelliniemi L, Yu DT, Granfors K. HLA-B27 modulates intracellular survival of Salmonella enteritidis in human monocytic cells. Eur J Immunol 1997;27:1331-8.

55 Ikawa T, Ikeda M, Yamaguchi A, Tsai WC, Tamura N, Seta N, et al. Expression of arthritis-causing HLA-B27 on Hela cells promotes induction of c-fos in response to in vitro invasion by Salmonella typhimurium. J Clin Invest 1998;101:263-72.

56 Ekman P. Host-microbe interactions in Salmonella-triggered reactive arthritis with special reference to HLA-B27 [dissertation]. Turku, Finland: University of Turku, 2000:37-8.

57 Huhtinen $\mathbf{M}$, Repo H, Laasila K, Jansson S-E, Kautiainen H, Karma A, et al. Systemic inflammation and innate immune response in patients with previous anterior uveitis. Br J Ophthalmol 2002;86:412-17.

58 Krutzik SR, Sieling PA, Modlin RL. The role of Toll-like receptors in host defence against microbial infection. Curr Opin Immunol $2001 ; 13: 104-8$. 